\title{
Species richness of fern and lycophyte in an urban park in the Rio dos Sinos basin, Southern Brazil
}

\author{
Schmitt, JL. ${ }^{\mathrm{a} *}$ and Goetz, MNB. ${ }^{\mathrm{b}}$

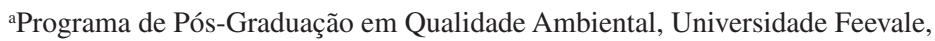 \\ Rod. RS-239, 2755, CEP 93352-000, Novo Hamburgo, RS, Brazil \\ 'Instituto de Ciências da Saúde,Universidade Feevale, Rod. RS 239, 2755, \\ CEP 93352-000, Novo Hamburgo, RS, Brazil \\ *e-mail: jairols@feevale.br
}

Received February 21, 2010 - Accepted April 29, 2010 - Distributed December 31, 2010

(With 1 figure)

\begin{abstract}
In the northeastern region of the State of Rio Grande do Sul in Southern Brazil, specifically in the Rio dos Sinos basin, urban parks are an important alternative for the conservation of the remaining natural habitats, as well as for the maintenance and perpetuation of biodiversity. A floristic survey of fern and lycophyte species in the Parque Municipal Henrique Luís Roessler (PMHLR) (29 41' S and 51 06' W; alt. 16.4 m) in Novo Hamburgo, (State of Rio Grande do Sul, RS) described their life-forms, as well as substrates and preferential environments. Forty-three species, 30 genera and 15 families were found, 39 of which were ferns. The hemicryptophytes had the highest species richness (26), 17 of which were repent, and nine, rosulate. Most species were found in terrestrial substrates (32) and inside the forest (29). Species richness in the PMHLR corresponded to about $13 \%$ of the total fern and lycophyte species listed for the State of Rio Grande do Sul, which demonstrates the importance of conservation areas in the Rio dos Sinos basin as an alternative to the preservation of local biodiversity.
\end{abstract}

Keywords: floristic survey, pteridophytes, protected areas, Southern Brazil.

\section{Riqueza de espécies de samambaias e licófitas em um parque urbano na bacia do Rio dos Sinos, sul do Brasil}

\begin{abstract}
Resumo
No sul do Brasil, no nordeste do Rio Grande do Sul, especificamente na bacia do rio dos Sinos, os parques urbanos representam uma alternativa importante para a conservação de remanescentes de hábitats naturais, bem como a manutenção e a perpetuação da biodiversidade. Foi realizado um inventário florístico das espécies de samambaias e licófitas ocorrentes no Parque Municipal Henrique Luís Roessler (PMHLR) (29 41' S e 51º6’ W; alt. 16,4 m), no município de Novo Hamburgo (RS), enfatizando a forma biológica e de crescimento, bem como o substrato e ambiente preferencial das plantas. Foram registradas 43 espécies, 30 gêneros e 15 famílias, das quais 39 são samambaias. A forma de vida hemicriptófita apresentou a maior riqueza específica (26), sendo 17 espécies de crescimento reptante e nove de rosulado. A maioria das espécies foi encontrada em substrato terrícola (32) e ocorreram no interior florestal (29). A riqueza específica registrada no PMHLR representou cerca de 13\% do total de espécies de samambaias e licófitas listadas para o Rio Grande do Sul e demonstra a importância de unidades de conservação, na bacia do rio dos Sinos, como alternativa de preservação da biodiversidade local.
\end{abstract}

Palavras-chave: inventário florístico, pteridófitas, áreas protegidas, sul do Brasil. 


\section{Introduction}

The Atlantic Forest is a priority area for preservation, and is listed as a world hotspot due to its biodiversity and its high degree of endemism, as well as to the elevated level of threat to which it is exposed (Myers et al., 2000). In the Southern region of Brazil, in the State of Rio Grande to Sul, only $4.7 \%$ of its original area is left (MMA/SBF, 2002), and in the northeastern area of the state, particularly in the Rio do Sinos basin, forest fragments are, mostly, part of the semideciduous seasonal forest that belongs to the Atlantic Forest (Teixeira et al., 1986).

Forests have a high diversity of ferns and lycophytes (Tryon, 1985), and the Atlantic Forest is the Brazilian biome where their greatest occurrence is found (Prado, 2003). Ferns and lycophytes are distributed from sea level up to almost the upper limits of montane vegetation in tropical regions (Windisch, 1992). To grow in such a wide variety of habitats, these plants have different life-forms, as well as almost all types of adaptations and forms of angiosperm growth (Holttum, 1938).

Moran (2008) estimated that there are 13,600 fern and lycophyte species in the world, and that about 1,2001,300 are found in Brazil (Prado, 2003). In Rio Grande do Sul, 19 lycophyte species (Lorscheitter et al., 1998) and 322 fern species (Falavigna, 2002) have been described.

Parks are some of the few natural habitats that remain in urban areas, and their importance for the preservation of biodiversity is great (Terborgh and Schaik, 2002). Due to their floristic and faunistic components, their hydrological characteristics and their influence on microclimate conditions, urban parks are important for environmental quality in cities (Mohr, 1985). In Brazil, there has been growing concern about the preservation of small fragments of natural green areas still found in our cities, which has added cultural and scientific value to these areas (Siqueira, 2008). In the Rio dos Sinos basin in Rio Grande do Sul, the Parque Municipal Henrique Luís Roessler (PMHLR) is the largest remaining forest in the urban area of the municipality of Novo Hamburgo (RS). The park was created by Municipal Law \# 2,425 on March 27, 2007, and recently recognised as a preservation area by Decree \# 4,129 of December 2009 issued by the Novo Hamburgo City Hall.

Some important floristic inventories of lycophyte and fern species in protected areas of Rio Grande do Sul were conducted by Bueno and Senna (1992) in the Parque Nacional dos Aparados da Serra, in Cambará do Sul, by Falavigna (2002) in the Parque da Ferradura, by Schmitt et al. (2006) in the Floresta Nacional de Canela (FLONA), and by Santos and Windisch (2008) in the Área de Proteção Ambiental do Morro da Borússia in Osório.

This study conducted an inventory of the fern and lycophyte species in PMHLR, described life-form, growth, substrate and preferential environment of these species, and analysed the similarity of the park's floristic composition with that of other preservation areas in Rio Grande do Sul.

\section{Material and Methods}

\subsection{Study area}

The field work was conducted in the Parque Municipal Henrique Luís Roessler (PMHLR) (29 41' S and 51 ${ }^{\circ} 06^{\prime} \mathrm{W}$; alt. $16.4 \mathrm{~m}$ ), which is one of the preservation areas of the Rio dos Sinos basin, located in the municipality of Novo Hamburgo in the State of Rio Grande do Sul (RS), Southern Brazil. The park area is currently about 54 ha, made up of dry fields, wet areas, and secondary forests (Weisheimer et al., 1996) classified as a semideciduous seasonal lowland forest (Teixeira et al., 1986). The oldest remaining areas of the PMHLR forest reached an intermediate stage of regeneration (Weisheimer et al., 1996). In Rio Grande do Sul, the climate is humid all year long (Buriol et al., 2007) and according to the closest meteorological station, located in the municipality of Campo Bom (29 $41^{\prime} \mathrm{S}$ and $51^{\circ} 03^{\prime} \mathrm{W}$; alt. $25.8 \mathrm{~m}$ ), mean annual rainfall was $1,649.5 \mathrm{~mm}$, and the mean annual temperature, $19.5^{\circ} \mathrm{C}$ in the last 20 years. The soil is composed of clay mixed with fine sand and a large amount of organic matter; it is reddish-brown and not very compacted (Weisheimer et al., 1996), and was classified as hydromorphic eutrophic arenic planosol (Streck et al., 2002).

\subsection{Floristic survey}

Bimonthly field trips between 2005 and 2008 were made to record lycophyte and fern species found in the PMHLR. The material collected was analysed according to the field method described by Windisch (1992). Voucher material was deposited in the Herbarium Anchieta (PACA) of the Universidade do Vale do Rio dos Sinos, in the city of São Leopoldo, and duplicates were deposited in the botanical laboratory of Universidade Feevale, in Novo Hamburgo, in the State of Rio Grande do Sul. Taxonomic identification was conducted using specialised references, comparisons to material deposited in herbaria, and consultation with specialists. The families were arranged according to the system described by Smith et al. (2006) and modifications introduced by Smith et al. (2008). Species were classified according to life-forms following the system described by Raunkiaer (1934) and adapted by Mueller-Dombois and Ellenberg (1974) and Senna and Waechter (1997). The substrates were classified as: terrestrial - species that occur only in the ground; hemicorticicolous - species with roots in the soil that climb into phorophyte and maintain connections with it during part of its life cycle; and corticicolous - species that grow in tree trunks. The preferential environment for each species was recorded, and the following sites were considered: field, bank, margin of forest, inside the forest, and humid environment.

The specific composition of ferns and lycophytes was compared with that described by other authors for parks or preservation areas in the State of Rio Grande do Sul: Parque Nacional dos Aparados da Serra (Bueno and Senna, 1992), the Floresta Nacional de Canela (Schmitt et al., 2006), the Parque da Ferradura (Falavigna, 2002), and the Morro da Borússia (Santos and Windisch, 2008). The principal 
vegetation types of the sites followed the classification presented by the RADAMBRASIL Project (Teixeira et al., 1986). A matrix of presence and absence of species was used to compare these areas with the Jaccard coefficient of similarity followed by cluster analysis (paired groups) using the statistical software Paleontological Statistics (PAST) (Hammer et al., 2003).

\section{Results}

Forty-three species, 15 families and 30 genera were identified. Ferns were predominant, with 39 species, 13 families and 27 genera. Four species of lycophytes belonging to two families and three genera were found. Polypodiaceae had the highest species richness (eight species), followed by Thelypteridaceae and Pteridaceae (five species each). These three families accounted for $42 \%$ of all species. Dennstaedtiaceae, Dicksoniaceae, Osmundaceae and Selaginellaceae were the families with the least richness (one species each). The richest genus was Thelypteris Schmidel (four species), and 22 genera had only one species (Table 1).
Most species were hemicryptophytes (26), and repent species (17) predominated over those with a rosulate growth (9). The second richest category was epiphytes (10), and, except for Asplenium gastonis Fée, all other species were repent. These two life-forms accounted for $84 \%$ of the total species richness, whereas the other four categories had at the most four species each: rhizomatous geophytes (1), rosulate phanerophytes (4), rosulate chamaephytes (1) and a scandent hemiepiphyte (1) (Table 1).

The analysis of preferential substrates showed that 32 species were terrestrial, and 10 were corticicolous. Only the Blechnum binervatum subsp. acutum (Desv.) R. M. Tryon \& Stolze was classified as hemicorticicolous. Most species (29) in the PMHLR were found inside the forest. Cyathea atrovirens (Langsd. \& Fisch.) Domin was the only arborescent fern, also found outside the forest areas.

The dendrogram built according to the floristic similarity analysis, revealed two groups: the first was formed only by Parque Nacional dos Aparados da Serra, where there was mixed humid forest (A); and the second was formed also by other areas (B). Group B had two subgroups, one of them formed only by the Parque da Ferradura $(\mathrm{Ba})$, where there

Table 1. Fern and lycophyte species in the Parque Municipal Henrique Luís Roessler in Novo Hamburgo, State of Rio Grande do Sul, Brazil. MF: margin of forest; IF: inside forest; Fld: field; HuE: humid environment; Ban: bank; Ros: rosulate; Rep: repent; Sca: scandent, Hc: hemicryptophyte; Ep: epiphyte; He: hemiepiphyte; Cha: chamaephyte; Pha: phanerophyte; Geo: geophyte; rhi: rhizomatous; Ter: terrestrial; Cor: corticicolous; HCor: hemicorticicolous.

\section{Family/species}

\section{Ecological aspects}

Habitat Life forms Substrate

Ferns

Anemiaceae

Anemia tomentosa (Savigny) Sw.

Anemia phyllitidis (L.) Sw.

Aspleniaceae

Asplenium claussenii Hieron.

Asplenium gastonis Fée

\section{Blechnaceae}

Blechnum binervatum subsp. acutum (Desv.) R. M. Tryon \& Stolze

Blechnum brasiliensis Desv.

Blechnum occidentale L.

\section{Cyatheaceae}

Alsophila setosa Kaulf.

Cyathea delgadii Sternb.

Cyathea atrovirens (Langsd. \& Fisch.) Domin

\section{Dennstaedtiaceae}

Pteridium aquilinum (L.) Kuhn var. arachnoideum (Kaulf.) Brade

\section{Dicksoniaceae}

Dicksonia sellowiana Hook.

MF

IF

Hc Rep

Hc Ros

Ter

IF

IF

Hc Ros

Ep Ros

Ter

Cor

$\begin{array}{ccc}\text { IF } & \text { He Sca } & \text { Hcor } \\ \text { IF } & \text { Cha Ros } & \text { Ter } \\ \text { Fld/IF/MF } & \text { Hc Ros } & \text { Ter }\end{array}$

Fld/IF/MF Hc Ros Ter

$\begin{array}{ccc}\text { IF } & \text { Pha Ros } & \text { Ter } \\ \text { IF } & \text { Pha Ros } & \text { Ter } \\ \text { MF/IF/HuE } & \text { Pha Ros } & \text { Ter }\end{array}$

Fld/MF Geo Rhi Ter

IF Pha Ros Ter

Dryopteridaceae

Ctenitis submarginalis (Langsd. \& Fisch.) Ching

Lastreopsis amplissima (C. Presl) Tindale

Rumohra adiantiformis (G. Forst.) Ching

$\begin{array}{clc}\text { MF/IF } & \text { Hc Rep } & \text { Ter } \\ \text { IF } & \text { Hc Rep } & \text { Ter } \\ \text { MF/IF } & \text { Hc Rep } & \text { Ter }\end{array}$


Table 1. Continued...

Family/species

\section{Gleicheniaceae}

Dicranopteris flexuosa (Schrad.) Underw.

Gleichenia angusta (Klotzsch ex Sturm) Maxon ex Lellinger

\section{Osmundaceae}

Osmunda regalis $\mathrm{L}$.

\section{Polypodiaceae}

Campyloneurum nitidum (Kaulf.) C. Presl

Microgramma vacciniifolia (Langsd. \& Fisch.) Copel.

Microgramma squamulosa (Kaulf.) de la Sota

Niphidium rufosquamatum Lellinger

Pecluma pectinatiformis (Lindm.) M.G. Price

Pleopeltis angusta Humb. \& Bonpl. ex Willd.

Polypodium catharinae Langsd. \& Fisch.

Polypodium hirsutissimum Raddi

\section{Pteridaceae}

Adiantopsis chlorophylla (Sw.) Fée

Adiantum raddianum $\mathrm{C}$. Presl

Doryopteris pedatta var. multipartitta (Fée) R. M. Tryon

Pityrogramma calomelanos (L.) Link

Vittaria lineata (L.) Sm.

\section{Thelypteridaceae}

Macrothelypteris torresiana (Gaudich.) Ching

Thelypteris brevisora (Rosenst.) Ponce

Thelypteris decurtata (Link) Sota

Thelypteris hispidula (Decne.) C.F. Reed

Thelypteris oligocarpa (Humb. et Bonpl. ex Willd.) Ching

Woodsiaceae

Diplazium cristatum (Desr.) Alston

Diplazium herbaceum Fée

Diplazium petersenii (Kunze) H. Christ.

\section{Lycophytes}

\section{Lycopodiaceae}

Lycopodiella alopecuroides (L.) Cranfill

Lycopodiella cernua (L.) Pic. Serm.

Lycopodium clavatum $\mathrm{L}$.

\section{Selaginellaceae}

Selaginella muscosa Spring
Ecological aspects

Habitat Life forms Substrate

$\begin{array}{lll}\text { HuE } & \text { Hc Rep } & \text { Ter } \\ \text { HuE } & \text { Hc Rep } & \text { Ter }\end{array}$

HuE Hc Ros Ter

$\begin{array}{lll}\text { IF } & \text { Ep Rep } & \text { Cor } \\ \text { IF } & \text { Ep Rep } & \text { Cor } \\ \text { IF } & \text { Ep Rep } & \text { Cor } \\ \text { IF } & \text { Ep Rep } & \text { Cor } \\ \text { IF } & \text { Ep Rep } & \text { Cor } \\ \text { IF } & \text { Ep Rep } & \text { Cor } \\ \text { IF } & \text { Ep Rep } & \text { Cor } \\ \text { IF } & \text { Ep Rep } & \text { Cor }\end{array}$

Fld Hc Rep Ter

IF Hc Rep Ter

IF Hc Ros Ter

HuE Hc Ros Ter

IF Ep Rep Cor

IF Hc Ros Ter

IF Hc Ros Ter

IF Hc Rep Ter

IF Hc Rep Ter

IF Hc Rep Ter

IF Hc Ros Ter

IF Hc Rep Ter

IF Hc Rep Ter

$\begin{array}{lll}\text { HuE } & \text { Hc Rep } & \text { Ter } \\ \text { Ban } & \text { Hc Rep } & \text { Ter } \\ \text { Ban } & \text { Hc Rep } & \text { Ter }\end{array}$

IF Hc Rep Ter

were mixed humid and semideciduous seasonal forests (predominant); and the other by the Morro da Borússia (dense humid forest), the Floresta Nacional de Canela (mixed humid forest), and the PMHLR (semideciduous seasonal forest) $(\mathrm{Bb})$, where the vegetation types were also associated with the Atlantic Forest sensu lato (Collares, 2006). The areas with the greatest similarity of species composition between each other were the Floresta Nacional de Canela and the PMHLR (Figure 1).

\section{Discussion}

Species richness in the PMHLR corresponded to about $13 \%$ of the total fern and lycophyte species listed for the State of Rio Grande do Sul. The total number of species in this study was close to the number found in the Parque Nacional dos Aparados da Serra (50) by Bueno and Senna (1992), in the Parque da Ferradura (52) by Falavigna (2002), in the Morro da Borússia (53) by Santos and Windisch (2008), and in the Floresta Nacional de Canela 
Similarity

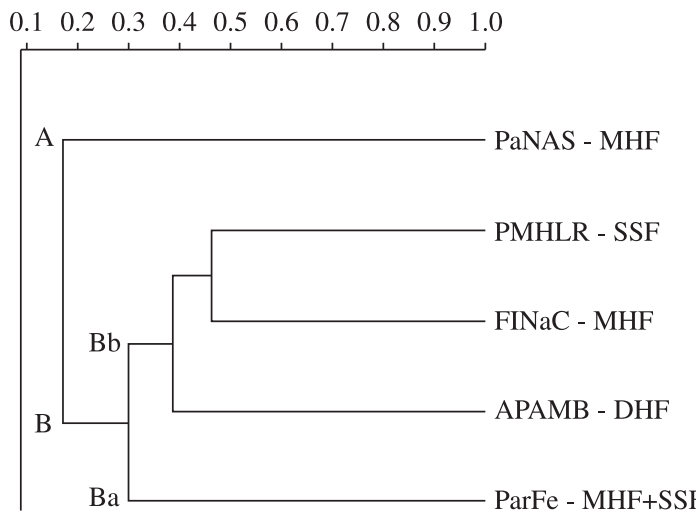

Figure 1. Dendrogram of floristic similarity in five protected areas in the State of Rio Grande do Sul according to the specific description of ferns and lycophytes. PaNAS: Parque Nacional dos Aparados da Serra; APAMB: Área de Proteção Ambiental Morro da Borússia; FINaC: Floresta Nacional de Canela; PMHLR: Parque Municipal Henrique Luís Roessler; ParFe: Parque da Ferradura; MHF: Mixed Humid Forest; DHF: Dense Humid Forest; SSF: Semideciduous Seasonal Forest.

(58) by Schmitt et al. (2006), their findings, however, were distributed in areas at least eight times larger than the area of the PMHLR. The fact that PMHLR has the smallest area and that the number of species recorded was similar to other sites in the state shows the high species richness of the Park. Through these comparisons and considering that other authors showed that the richness of ferns and lycophytes may not be influenced by fragment size (Lwanga et al., 1998; Paciencia and Prado, 2004, 2005b), it was clear the importance of creating and maintaining protected areas in the Rio dos Sinos basin as an alternative for local biodiversity preservation. Similarly to our results, all those inventories found that Polypodiaceae was the family with the largest representation, and, except in the Parque da Ferradura, Thelypteris was among the richest genera.

The association of hemicryptophytes with the greatest richness followed by epiphytes in the PMHLR was also found by Falavigna (2002), Schmitt et al. (2006) and Santos and Windisch (2008). Perennating gemmae of hemicryptophytes protected by soil and dead leaves that fall from the plant itself or from forest trees (Raunkier, 1934) may favour the generalised occurrence of this form of life in different environments of the PMHLR. Polypodiaceae had only epiphytic species in this study, and our findings place it among the richest epiphytic families worldwide (Benzing, 1990). The several adaptations of this family (Benzing, 1990; Waechter, 1992; Müller et al., 1981) favour the occurrence of a greater number of species in the epiphytic environment.

Phanerophytes included all the arborescent fern species (Cyatheaceae and Dicksoniaceae) in the Rio dos Sinos basin, or four of the seven found in the State of Rio Grande do Sul (Lorscheitter et al., 1999). Alsophila setosa Kaulf. Cyathea atrovirens, C. delgadii Sternb. (Cyatheaceae) and Dicksonia sellowiana Hook. (Dicksoniaceae) are targeted by extractive actions, and are used in decoration or landscaping (Tryon RM. and Tryon AF., 1982; Windisch, 2002), as fence stakes (Corrêa, 1984) and to manufacture fibre handicrafts (Fernandes, 2000). Due to its intense economic use, Dicksonia sellowiana was included in the Official Lists of Endangered Plant Species (Normative Instruction of September, 2008, MMA, and RS State Decree \# 42,099) and in Appendix II of the International Convention of Endangered Wild Flora and Fauna Species (CITES).

Cyathea atrovirens was the only phanerophytes species with more generalised occurrence in the PMHLR, probably because it has characteristics of heliomorphic plants, such as bright and small coriaceous blades (Fernandes, 1997), which are adaptations that contribute to species growth under different lighting conditions. Most of the park species were found inside the forest. Rain forests are favourable environments for fern and lycophyte diversity and abundance because they promote the development of a large spectrum of life-forms (Senna and Waechter, 1997).

The predominance of terrestrial species in the PMHLR was recorded by other authors, such as Bueno and Senna (1992), Falavigna (2002), Schmitt et al. (2006) and Santos and Windisch (2008). Only the Blechnum binervatum subsp. acutum has a preference for hemicorticicolous substrate; the individuals in this species germinate in the soil and later climb a phorophyte, apparently to produce fertile leaves (Dittrich et al., 2005).

The floristic similarity analysis revealed the heterogeneity of the specific composition of ferns and lycophytes among the sites under comparison. Considering that the sites with the same forest type were not more similar among each other, it was shown that vegetation type was not a determinant factor in floristic resemblance among the analysed areas.

The fact that PaNAS had the smallest similarity index indicated a singular floristic composition of this protected area, with 22 exclusive species. On the other hand, the strongest floristic affinity was seen between F1NaC and PMHLR, since these two sites share 31 species. Beside the forest type, some variables that were not considered for this study, such as soil (Tuomisto and Poulsen, 1996) and fragmentation (Paciencia and Prado, 2005a), may be influencing fern and lycophyte spatial distribution, reflecting on floristic affinity among the analysed areas.

Floristic inventories provide fundamental information about the specific composition of certain areas and enable the preparation of support material and databases that may be used for the advance of taxonomic, ecological and phytogeographical studies or for the reforestation of degraded areas (Souza et al., 2009). The description of the fern and lycophyte community in the PMHLR may contribute to the development of the knowledge base about the flora in protected areas of the Rio dos Sinos basin in the State of Rio Grande do Sul. However, it is necessary to increase the number of surveyed areas so that a full 
diagnosis of the flora in this basin may be available in the future.

Acknowledgements - We thank Universidade Feevale for funding this study; Novo Hamburgo City Hall for the authorisation to conduct this study in this area and for logistic support; Rodrigo Fleck and the other botanical laboratory trainees for their assistance with field and laboratory work.

\section{References}

BENZING, DH., 1990. Vascular epiphytes. Cambridge: Cambridge University Press, $354 \mathrm{p}$.

BUENO, RM. and SENNA, RM., 1992. Pteridófitas do Parque Nacional dos Aparados da Serra. I. Região do Paradouro. Pesquisas, Botânica, vol. 4, p. 5-12.

BURIOL, GA., ESTEFANEL, V., CHAGAS, AC. and EBERHARDT, D., 2007. Ciência Florestal, vol. 17, p. 91-100.

COLLARES, JER., 2006. Mapa de biomas do Brasil. In: MARIATH, JEA. and SANTOS, RP. (Orgs.). Os avanços da Botânica no início do século XXI: morfologia, fisiologia, taxonomia, ecologia e genética: Conferências Plenárias e Simpósios do $57^{\circ}$ Congresso Nacional de Botânica. Porto Alegre: Sociedade Botânica do Brasil, p. 336-339.

CORRÊA, MP., 1984. Dicionário das plantas úteis do Brasil e das exóticas cultivadas. $2^{\mathrm{a}}$ ed. Instituto Brasileiro de Desenvolvimento Florestal.

DITTRICH, VAO., WAECHTER, JL. and SALINO, A., 2005. Species richness of pteridophytes in a montane Atlantic rain forest plot of Southern Brazil. Acta Botanica Brasilica, vol. 19, no. 3 , p. $519-525$.

FALAVIGNA, TJ., 2002. Diversidade, formas de vida e distribuição altitudinal das pteridófitas do Parque da Ferradura, Canela (RS), Brasil. Universidade do Vale do Rio dos Sinos. [Dissertação de Mestrado].

FERNANDES, I., 1997. Taxonomia e fitogeografia de Cyatheaceae e Dicksoniaceae nas regiões sul e sudeste do Brasil. São Paulo: Universidade de São Paulo. [Tese de Doutorado].

-, 2000. Taxonomia dos representantes de Dicksoniaceae no Brasil. Pesquisas, Botânica, vol. 50, no. 1, p. 5-26.

HAMMER, Ø., HARPER, DAT. and RYAN PD., 2003. Paleontological Statistics - PAST. Version 1.18. [07/05/2003]. Available from: <http://folk.uio.no/ohammer/past>.

HOLTTUM, RE., 1938. The ecology of tropical pteridophytes. In VERDOORN, C. Manual of Peteridology. Hague: Martinius Nijhoff, p. 420-449.

LORSCHEITTER, ML., ASHRAF, AR., BUENO, RM. and MOSBRUGGER, V., 1998. Pteridophyte of Rio Grande do Sul flora, Brazil. Part I. Palaeontographica, vol. 246, p. 1-113.

LORSCHEITTER, ML., ASHRAF, AR., WINDSCH, PG. and MOSBRUGGER, V., 1999. Pteridophyte spores of Rio Grande do Sul flora, Brazil. PartII. Palaeontographica, vol. 251, p. 71-235.

LWANGA, JS., BALMFORD A. and BADAZA R., 1998. Assessing fern diversity: relative species richness and its environmental correlates in Uganda. Biodiversity and Conservation, vol. 7, p. $1387-1398$.

Ministério do Meio Ambiente - MMA. and Secretaria Nacional de Biodiversidade e Florestas - SBF, 2002. Avaliação e identificação de áreas e ações prioritárias para a conservação, utilização sustentável e repartição dos benefícios da biodiversidade nos biomas brasileiros. Brasília, DF: MMA/SBF, 404 p.

MOHR, U., 1985. A cidade, os espaços públicos e a vegetação. In Secretaria Municipal do Meio Ambiente (Org.). Contribuições técnico-científicas. Porto Alegre: Secretaria Municipal do Meio Ambiente, p. 255

MORAN, RC., 2008. Diversity, biogeography, and floristics. In RANKER, TA. and HAUFLER, CH. (Eds.), Biology and evolution offerns and lycophytes. Cambridge: Cambridge University Press, p. 367-394.

MÜLLER, L., STARNECKER, G. and WINKLER, S., 1981. Zur Ökologie epiphytisher Farne in Südbrasilien. I. Saugschuppen. Flora, vol. 171, p. 55-63.

MÜLLER-DOMBOIS, D. and ELLENBERG, H., 1974. Aims and methods of vegetation ecology. New York: Wiley International, p. 547.

MYERS, N., MITTERMEIER, RA., MITTERMEIER, CG., FONSECA, GAB. and KENT, J., 2000. Biodiversity hotspots for conservation priorities. Nature, vol. 403, p. 853-858.

PACIENCIA, MLB. and PRADO, J., 2004. Efeitos de borda sobre a comunidade de pteridófitas na Mata Atlântica da região de Una, sul da Bahia, Brasil. Revista Brasileira de Botânica, vol. 24, no. 4, p. 641-653.

-, 2005a. Distribuição espacial da assembléia de pteridófitas em uma paisagem fragmentada de Mata Atlântica no sul da Bahia, Brasil. Hoehnea, vol. 32, no. 1, p. 103-117.

-, 2005b. Effects of forest fragmentation on pteridophyte diversity in a tropical rain forest in Brazil. Plant Ecology, vol. 180, p. $87-104$.

PRADO, J., 2003. Revisões e monografias como base para a análise da diversidade, o quanto conhecemos sobre nossa flora. In JARDIM, MAG., BASTOS, MNC. and SANTOS, JUM. (Eds.). Desafios da Botânica Brasileira no Novo Milênio: Inventário, Sistematização e Conservação da Diversidade Vegetal. Belém: SBA, p. 278-279.

RAUNKIAER, C., 1934. The life forms of plants and statistical plant geography. Oxford: Clarendon, p. 632.

SANTOS, ACC. and WINDISCH, PG., 2008. Análise da pteridoflora da área de proteção ambiental do Morro da Borússia (Osório RS). Pesquisas, Botânica, vol. 59, p. 237-252.

SCHMITT, JL., FLECK, R., BURMEISTER, EL. and KIELINGRUBIO, MA., 2006. Diversidade e formas biológicas de pteridófitas da Floresta Nacional de Canela, Rio Grande do Sul: contribuição para o plano de manejo. Pesquisas, Botânica, vol. 57, p. 275-288.

SENNA, RM. and WAECHTER, JL., 1997. Pteridófitas de uma floresta com araucária. 1. Formas biológicas e padrões de distribuição geográfica. Iheringia, série Botânica, vol. 48, p. 41-58.

SIQUEIRA, JC., 2008. Fundamentos de uma biogeografia pra o espaço urbano. Pesquisas, Botânica, vol. 59, p. 191-210.

SMITH AR., PRYER, KM., SCHUETTPELZ, E., KORALL, P., SCHNEIDER, H. and WOLF, PG., 2008. Fern Classification. In RANKER, TA. and HAUFLER, CH. (Eds.). The Biology and Evolution of Ferns and Lycophytes. Cambridge: Cambridge University Press., p. 417-467. 
SMITH, AR., KATHLEEN, MP., SCHUETTPELZ, E., KORALL, P., SCHNEIDER, H. and WOLF, PG., 2006. A classification for extant ferns. Taxon, vol. 55, p. 705-731.

SOUZA, MC., KAWAKITA, K., SLUSARSKI, SR. and PEREIRA, GF., 2009. Vascular flora of the Upper Paraná River floodplain. Brazilian Journal of Biology, vol. 69, no. 2, p. 735-745.

STRECK, EV., KÄMPF, N., DALMOLIN, RSD., KLAMT, E., NASCIMENTO, PC. and SCHNEIDER, P., 2002. Solos do Rio Grande do Sul. Porto Alegre: UFRGS.

TEIXEIRA, MB., COURA-NETO, AB., PASTORE, U. and RANGEL-FILHO, ALR., 1986. Vegetação. In Instituto Brasileiro de Geografia e Estatística - IBGE. Levantamento de recursos naturais. Rio de Janeiro: IBGE, vol. 33, p. 541-620.

TERBORGH, J. and SCHAIK, C. van, 2002. Por que o mundo necessita de parques? In TERBORGH, J., SCHAIK, C. van, DAVENPORT, L. and RAO, M. Tornando os parques nacionais eficientes: estratégias para a conservação da natureza nos trópicos. Curitiba: Ed. da UFPR/Fundação O Boticário, p. 25-36.

TRYON, RM. and TRYON, AF., 1982. Ferns and allied plants with special reference to Tropical America. New York: Springer Verlag.
TRYON, RM., 1985. Fern speciacion and biogeography. In DYER, AF. and PAGE, CN. (Eds.). Biology of pteridophyte. The Royal Society of Edimburg, p. 353-360.

TUOMISTO, H. and POULSEN, AD., 1996. Influence of edaphic specialization on pteridophyte distribution in Neotropical Rain Forests. Journal of Biogeography, vol. 23, p. 283-293.

WAECHTER, JL., 1992. O epifitismo vascular na Planíce costeira do Rio Grande do Sul. São Carlos: Universidade Federal de São Carlos. [Tese de Doutorado].

WEISHEIMER, C., MAUHS, J. and SAUL, AFP., 1996. Plano de Manejo - Parque Municipal Henrique Luís Roessler - Parcão. Novo Hamburo, RS: Prefeitura Municipal de Novo Hamburgo, $31 \mathrm{p}$.

WINDISCH, PG., 1992. Pteridófitas da região norte-ocidental do estado de São Paulo. São José do Rio Preto, Universidade Estadual Paulista - UNESP, 110 p.

-, 2002. Fern conservation in Brazil. Fern Gazette, vol. 16, p. 295-300. 